\title{
HIGH BIODIVERSITY IN A CITY CENTRE: ODONATOFAUNA IN AN ABANDONED LIMESTONE QUARRY
}

\author{
RAFA $€$ BOBREK* \\ Polish Society for the Protection of Birds, Odrowąża 24, 05-270 Marki, Poland \\ * Corresponding author: rafal.bobrek@gmail.com
}

\begin{abstract}
Limestone quarries are known to be places where the diversity of xerothermophilic organisms is promoting diversity and in some, there are water bodies that potentially support the presence of hydrobionts. These include dragonflies (Insecta: Odonata), which, as amphibiotic insects, use both aquatic and terrestrial habitats. The purpose of this paper was to determine whether there was a high diversity of odonatofauna in an old limestone quarry with well-developed aquatic habitats, located in an urban environment in the Central-European city of Kraków (S Poland). For this purpose, dragonflies in the quarry were monitored regularly, focusing on the reproductive status and relative abundance of each species. In 2017-2018, 37 species belonging to seven families of Odonata were recorded in the quarry, which is $50 \%$ of the Poland's odonatofauna. Of these, 33 species were considered indigenous to the quarry. Among them, $30 \%$ were moderately urbanophobic or urbanophobic taxa. Habitat specialists made up 39\% of the species. Some rare and declining species, i.e. Leucorrhinia pectoralis and L. rubicunda, were abundant at this site. The study shows that a well-preserved secondary habitat, located in the centre of a city and not subject to urban management, can support a high diversity of odonates. Such limestone quarries in highly transformed urban environments can be valuable sites for this indicator group of organisms and should be identified, evaluated and conserved.
\end{abstract}

Keywords: anthropogenic habitat; damselflies; dragonflies; novel ecosystem; Odonata assemblage; secondary habitat; urban environment

\section{Introduction}

Progressive urbanization is considered to be one of the most important threats to biodiversity in the world (Grimm et al. 2008). In an increasingly degraded world, replacement (secondary) habitats are becoming increasingly important for maintaining local biodiversity (Tropek et al. 2010; Chester and Robson 2013; Buczyński 2015; Aronson et al. 2017). Their role is particularly important in strongly transformed urban environments, in which, among others, the size and character of patches of well-preserved habitats, their connectivity and diversity of management and history determine the level of biodiversity they support (Beninde et al. 2015; Aronson et al. 2017).

Examples of valuable replacement habitats are mineral extraction sites, such as quarries, mines, gravel- and sandpits (Chester and Robson 2013). During exploitation, such places undergo significant transformation in terms of the surface, soil, vegetation, water relations and pollution resulting in the destruction of the local ecosystem. However, when abandoned, they undergo spontaneous transition and develop valuable secondary habitats, which are colonized by numerous, often specialized species, typical of the early stages of ecological succession (Bétard 2013). Particularly high levels of biodiversity are present in abandoned limestone quarries, which despite their anthropogenic and replacement character, are often colonized by rich and diverse flora and fauna, including many of high conservation status or even by endangered species (Tropek et al. 2010). This is particularly well documented in the case of petrophilic and xerothermic organisms (Jefferson 1984; Beneš et al. 2003; Tropek and Konvicka 2008; Krauss et al. 2009; Tropek et al. 2010), which are favoured by rocky, calcium-rich soils and strong insolation. However, organisms associated with the small water bodies that form in abandoned quarries are less well studied. These include dragonflies, which have high dispersal abilities and quickly colonize newly created water bodies (Conrad et al. 1999). What is more, dragonflies are bioindicators of the quality of both stagnant and flowing water (Bulánková 1997; Osborn 2005; Kutcher and Bried 2014; Kietzka et al. 2018). This also applies to urban landscapes and dragonflies are a good model group for determining the effect of urbanization on biodiversity (Villalobos-Jiménez et al. 2016).

Although there are quite a few papers on dragonflies in abandoned limestone quarries (e.g. Rudolph 1976; Koeppel et al. 1995; Kuńka et al. 2008; INULA 2011; Fröhlich et al. 2012; Czerniawska-Kusza and Brożonowicz 2014; Gwardjan et al. 2015) there is still a paucity of detailed studies on odonate biodiversity in such habitats. It is postulated that the main limitation on considering bodies of freshwater of anthropogenic origin as refugia for biodiversity is the lack of recognition of their biocenotic value (Chester and Robson 2013). The significance of artificial waterbodies is underestimated in many biodiversity management programs and are often destroyed in the course of standard water management practices and urban development, which do not take into account their ecological importance (Chester and Robson 2013). The biocenotic role of water bodies located in city centres is particularly interesting. On one hand, they constitute a distinctive element enhancing diversity in homogenous, urbanized landscapes, and on the other, compared to natural biotopes, their colonization by organisms may be more difficult, even for dragonflies. This is related to the fact that urban surface waters are often characterized by high levels of pollution, high levels of 
nutrients, poor and structurally undifferentiated vegetation or concrete sides (Vermonden et al. 2009; Buczyński and Lewandowski 2011). What is more, these secondary habitats are sometimes considered to be ecological traps, in which reproduction is ineffective, as the incidents of colonizations and extinctions are frequent in such habitats (Harabiš and Dolny 2012). It is not surprising, therefore, that in cities, which are usually poor in water habitats, increasing urbanization results in loss in species diversity of dragonflies (Willigalla and Fartmann 2012). Studies on urbanization (rural-urban) gradients clearly show that the diversity of dragonfly assemblages decrease towards inner city areas (review in: Villalobos-Jiménez et al. 2016). The aim of this paper was to check whether a limestone quarry located in an urban environment in the core zone of a large city, can maintain a high species richness of odonatofauna. In addition, an attempt is made to assess whether this type of habitat could act as a refugium for water insects at local and supralocal scales.

\section{Material and Methods}

\section{Study site}

The research area is located in southern Poland, in Krakow, a city of around 800,000 inhabitants, covering an area of over $325 \mathrm{~km}^{2}$ (Fig. 1). The research was carried out in an abandoned "Liban" limestone quarry, located in

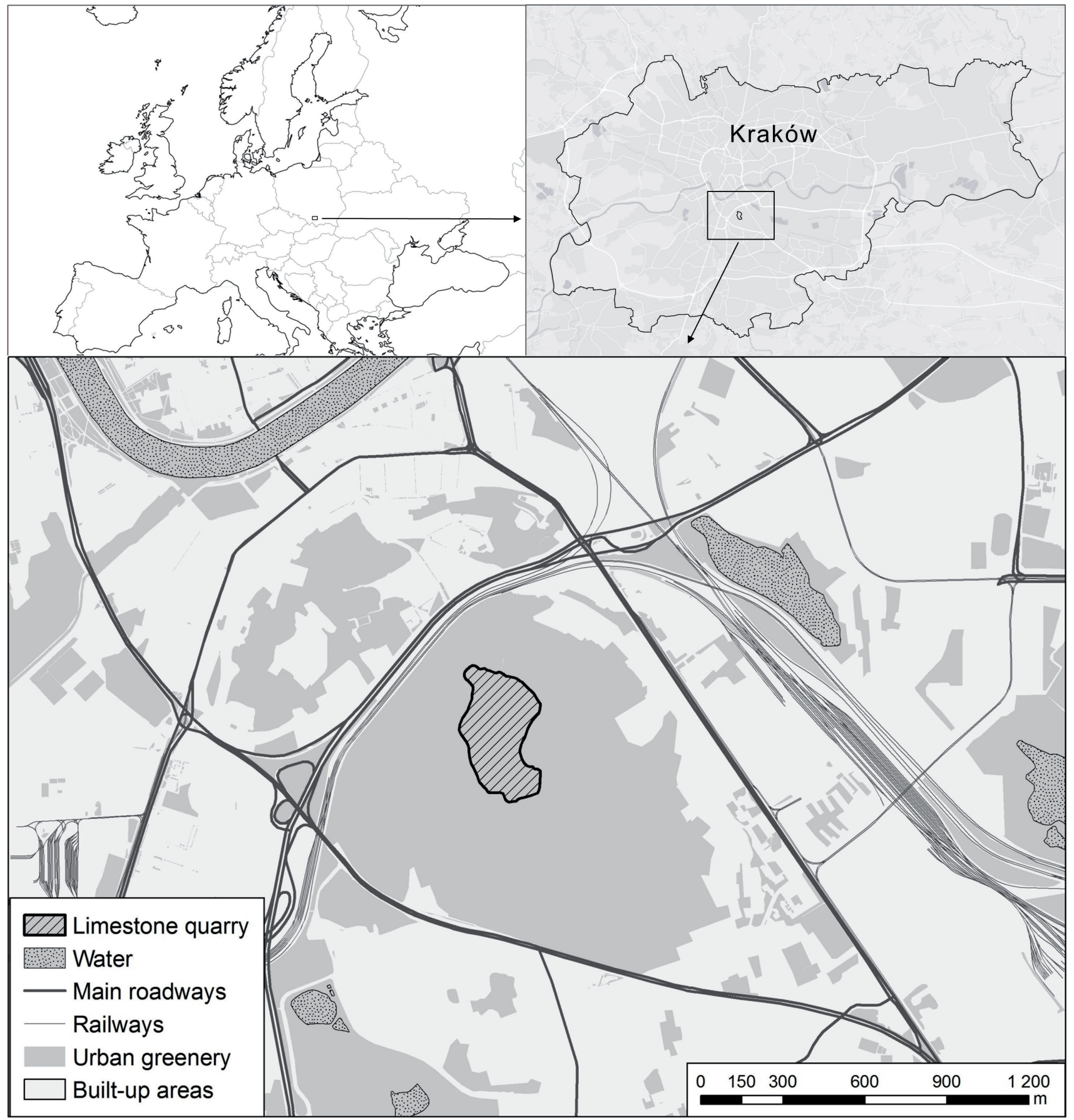

Fig. 1 Maps showing the location of the limestone quarry studied. 
the historical district in the central part of the city, only 3 $\mathrm{km}$ from the main square of the old town and $1 \mathrm{~km}$ from the Vistula river. The quarry covers an area of 10 ha and is bounded by almost vertical, rocky slopes. Limestone was excavated from here from the 14th century until 1986. At present, this site is not economically used or managed for any urban purpose and is undergoing slow and gradual ecological succession (Górecki and Seremet 2010). Significant parts of the quarry are subject to tourist pressure as they are popular places for Kraków's residents and tourists to walk. The quarry and its surroundings (the Krakus Mound, cemetery and allotments, geological nature reserve, historical site etc.) constitute an "island of greenery" in a dense urban development with many routes carrying heavy traffic (Fig. 1).

The quarry is characterized by high habitat diversity, with water, marsh and dry biotopes, constituting a complex mosaic of habitats. The character of this mosaic is shaped by significant fluctuations in the water level throughout the year and between years, resulting in a large inundation zone. In wet periods, many water-filled cavities and depressions in the bottom of the quarry combine and form a flooded area of about 2 ha. The water reservoirs are shallow and have rocky bottoms, covered by a thin layer of silt. They are astatic, which means most of them dry out completely in dry periods. However, two pools are deeper and more permanent, retaining water even during droughts. Most of the water biotopes are strongly insolated and heat up quickly over the course of a season, although there are also parts shaded by vegetation. The water is clear, which indicates a low nutrient content. There is a lack of naturally occurring fish there, but there are introduced goldfish, Carassius auratus.

All of the water bodies except one are characterized by well-developed and diverse submerged and emergent vegetation. The elodeids are mainly Myriophyllum spp. Ceratophyllum spp., Potamogeton lucens, Batrachium spp. and water mosses. Nimfeids, occur in the deeper parts and are mainly Potamogeton natans and Polygonum amphibium. Extensive areas are occupied by helophytes, mostly Juncus spp., Schoenoplectus spp. Eleocharis spp., Carex spp., Typha latifolia, T. angustifolia and Phragmites australis, which are accompanied by species such as Alisma plantago-aquatica, Solanum dulcamara and Lythrum salicaria. The area surrounding the water bodies is overgrown with meadow, grassland and rock communities (wet as well as xerothermic), and large areas are also occupied by willow bushes, Salix spp. Willows definitely dominate the tree layer, which also includes Betula pendula and Populus tremula mainly in the higher and non-flooded areas. The habitat mosaic also includes the surfaces of bare rock and steep limestone walls along with the rocky heaps and rubble at the bases of these walls.

\section{Sampling and data analysis}

Fieldwork in the quarry was carried out in 2017 and 2018. In 2017, between April 20 and August 18, there were 7 visits (1-2 in a month) to the quarry and in 2018, 19 visits (on average every 10-14 days) between April 15 and October 14. Each visit took from $1 \mathrm{~h} 15 \mathrm{~min}$ to $5 \mathrm{~h}$ $10 \mathrm{~min}$ (average $3 \mathrm{~h} 44 \mathrm{~min}$ ). Altogether, the 26 visits lasted a total of $97 \mathrm{~h} 25 \mathrm{~min}$. Observations were made mainly during the period when the adult odonates were most active, which was between 11:30 and 15:30 h CEST (UTC + 02:00), usually on bright and sunny days, when it was not raining, there was low cloud cover and light wind.

The quarry was sampled each time along a similar route, when adult odonates were observed (with the naked eye and using binoculars) and, when necessary, the identification of the species was confirmed by catching individuals using a sweep net. Many observations were also photographically documented. In addition, exuviae were also collected. On each visit, information was collected on the reproductive behaviour and the relative numbers of each species. Each type of behaviour recorded was classified in terms of the probability of it indicating a species had reproduced at the quarry, as unconfirmed, probable or confirmed (Table 1). On the basis of all the field visits, the highest category of behaviour was determined for each species. Indigenous species were considered to be those, for which the reproduction category was probable or confirmed. A relative abundance index was used to determine the quantitative relationships between particular species. This index indicates the minimum number of dragonflies observed during a visit, for which there was no doubt that they were different individuals. The highest category of the relative number of individuals recorded in a visit (Table 1) was used as a general index of abundance for each species, regardless of the numbers recorded on other visits.

\section{Results}

In 2017-2018, 37 species of odonates were recorded in "Liban" quarry, including 16 belonging to the suborder Zygoptera and 21 to the suborder Anisoptera (Table 1) belonging to seven families: Calopterygidae (2 species), Platycnemididae (1), Lestidae (5), Coenagrionidae (8), Aeshnidae (8), Corduliidae (1) and Libellulidae (12). Of these species 28 were confirmed as reproducing and five as probably reproducing there. That is, 33 species (12 Zygoptera and 21 Anisoptera) were considered to be indigenous to the quarry, although these species differed in their reproductive behaviour (Table 1). For the four remaining species (Calopteryx splendens, C. virgo, Platycnemis pennipes, Pyrrhosoma nymphula) there was no evidence that they reproduced in this quarry (Table 1 ), and were considered to be non-indigenous, vagrant species. Thus the odonates that reproduced in the quarry belonged to five families.

The seven most abundant odonates recorded are generally very numerous and formed the core of the local odonatofauna. These included the Zygoptera: Coenagri- 
Table 1 List of Odonata species recorded in the "Liban" quarry in Kraków in the years 2017-2018. The status of reproduction, behaviour and relative abundance are provided for each species. Reproduction was considered unconfirmed (REC - adult recorded), probable (TER territorial behaviour, JUV - juvenile, TAN - tandem, COP - copulation ring) or confirmed (OVI - oviposition, EXU - exuvia, TEN - teneral imago). The code 'REC' is omitted for species for which any higher code of behaviour was recorded. Five categories of abundance were used: (i) 1 (single), (ii) 2-10 (scarce), (iii) 11-20 (fairly numerous), (iv) 21-50 (numerous), (v) >50 (very numerous). These terms are used throughout the text. The last column contains the classification (according to Willigalla and Fartmann 2010) of species based on the strength of their connection with urban environments.

\begin{tabular}{|c|c|c|c|c|c|}
\hline No. & Species & Codes of behaviour & Reproduction & Abundance & $\begin{array}{l}\text { Urban environment } \\
\text { connection }\end{array}$ \\
\hline 1. & Calopteryx splendens (Harris, 1782) & REC & unconfirmed & scarce & urbanoneutral \\
\hline 2. & Calopteryx virgo (Linnaeus, 1758) & REC & unconfirmed & single & urbanoneutral \\
\hline 3. & Lestes dryas (Kirby, 1890) & TEN, OVI, COP, TAN, JUV & confirmed & very numerous & urbanoneutral \\
\hline 4. & Lestes sponsa (Hansemann, 1823) & TEN, OVI, COP, TAN, JUV, TER & confirmed & very numerous & urbanoneutral \\
\hline 5. & Lestes virens (Charpentier, 1825) & TEN, OVI, COP, TAN, JUV & confirmed & very numerous & moderately urbanophobic \\
\hline 6. & $\begin{array}{l}\text { Chalcolestes viridis (Vander Linden, } \\
\text { 1825) }\end{array}$ & OVI, COP, TAN & confirmed & scarce & moderately urbanophilous \\
\hline 7. & Sympecma fusca (Vander Linden, 1820) & TEN, OVI, COP, TAN, JUV & confirmed & numerous & urbanoneutral \\
\hline 8. & Platycnemis pennipes (Pallas, 1771) & REC & unconfirmed & scarce & urbanoneutral \\
\hline 9. & Ischnura elegans (Vander Linden, 1820) & TEN, COP, JUV & confirmed & very numerous & moderately urbanophilous \\
\hline 10. & Ischnura pumilio (Charpentier, 1825) & TEN, COP & confirmed & scarce & urbanoneutral \\
\hline 11. & $\begin{array}{l}\text { Enallagma cyathigerum (Charpentier, } \\
\text { 1840) }\end{array}$ & OVI, COP, TAN, JUV & confirmed & numerous & urbanoneutral \\
\hline 12. & Coenagrion puella (Linnaeus, 1758) & TEN, OVI, COP, TAN, TER & confirmed & very numerous & moderately urbanophilous \\
\hline 13. & $\begin{array}{l}\text { Coenagrion pulchellum (Vander Linden, } \\
1825 \text { ) }\end{array}$ & OVI & confirmed & scarce & moderately urbanophobic \\
\hline 14. & Erythromma najas (Hansemann, 1823) & TEN, OVI, COP, TAN, TER & confirmed & numerous & urbanoneutral \\
\hline 15. & $\begin{array}{l}\text { Erythromma viridulum (Charpentier, } \\
\text { 1840) }\end{array}$ & OVI, TAN, TER & confirmed & fairly numerous & urbanoneutral \\
\hline 16. & Pyrrhosoma nymphula (Sulzer, 1776) & REC & unconfirmed & single & urbanoneutral \\
\hline 17. & Brachytron pratense (O. F. Müller, 1764) & TER & probable & scarce & moderately urbanophobic \\
\hline 18. & Aeshna affinis (Vander Linden, 1820) & COP, TER & probable & fairly numerous & moderately urbanophobic \\
\hline 19. & Aeshna cyanea (O. F. Müller, 1764) & EXU, OVI, TER & confirmed & scarce & moderately urbanophilous \\
\hline 20. & Aeshna grandis (Linnaeus, 1758) & OVI, TER & confirmed & scarce & urbanoneutral \\
\hline 21. & Aeshna isoceles (O. F. Müller, 1767) & OVI, TER & confirmed & scarce & moderately urbanophobic \\
\hline 22. & Aeshna mixta (Latreille, 1805) & EXU, TER & confirmed & scarce & moderately urbanophilous \\
\hline 23. & Anax imperator (Leach, 1815) & EXU, OVI, TER & confirmed & fairly numerous & moderately urbanophilous \\
\hline 24. & Anax parthenope (Sélys, 1839) & OVI, TAN, TER & confirmed & scarce & moderately urbanophobic \\
\hline 25. & Cordulia aenea (Linnaeus, 1758) & OVI, TER & confirmed & scarce & urbanoneutral \\
\hline 26. & Libellula depressa (Linnaeus, 1758) & TER & probable & scarce & urbanoneutral \\
\hline 27. & Libellula quadrimaculata (Linnaeus, 1758) & OVI, COP, TAN, TER & confirmed & very numerous & urbanoneutral \\
\hline 28. & Orthetrum cancellatum (Linnaeus, 1758) & OVI, JUV & confirmed & scarce & moderately urbanophilous \\
\hline 29. & Crocothemis erythraea (Brullé, 1832) & OVI, COP, JUV, TER & confirmed & fairly numerous & moderately urbanophobic \\
\hline 30. & Sympetrum danae (Sulzer, 1776) & OVI, COP, TER & confirmed & numerous & urbanoneutral \\
\hline 31. & Sympetrum flaveolum (Linnaeus, 1758) & TER & probable & single & urbanoneutral \\
\hline 32. & Sympetrum meridionale (Sélys, 1841) & TEN, JUV, TER & confirmed & scarce & urbanophobic \\
\hline 33. & $\begin{array}{l}\text { Sympetrum sanguineum (O. F. Müller, } \\
\text { 1764) }\end{array}$ & TEN, OVI, COP, TAN, JUV, TER & confirmed & numerous & moderately urbanophilous \\
\hline 34. & $\begin{array}{l}\text { Sympetrum striolatum (Charpentier, } \\
1840 \text { ) }\end{array}$ & TEN, OVI, COP, TAN, JUV, TER & confirmed & very numerous & urbanoneutral \\
\hline 35. & Sympetrum vulgatum (Linnaeus, 1758) & TEN, JUV, TER & confirmed & single & urbanoneutral \\
\hline 36. & $\begin{array}{l}\text { Leucorrhinia pectoralis (Charpentier, } \\
\text { 1825) }\end{array}$ & OVI, COP, TAN, JUV, TER & confirmed & numerous & moderately urbanophobic \\
\hline 37. & Leucorrhinia rubicunda (Linnaeus, 1758) & TER & probable & fairly numerous & moderately urbanophobic \\
\hline
\end{tabular}


on puella, Ischnura elegans, Lestes sponsa, L. dryas and L. virens and Anisoptera: Libellula quadrimaculata and Sympetrum striolatum (Table 1). Fewer species were categorized as numerous or fairly-numerous (6 and 5 species, respectively). Fifteen species were categorised as scarce and single individuals of four species were recorded on only one visit. There were low numbers of four non-indigenous species, two of which were categorised as scarce and the other two were only recorded as single individuals (Table 1).

\section{Discussion}

\section{Odonata assemblage in the limestone quarry}

In Poland, there are currently 74 species of odonates recorded, 71 of which are indigenous species and breed here (Bernard et al. 2009; Buczyński et al. 2019). Therefore, the 37 species recorded in 2017-2018 in "Liban" quarry, make up $50 \%$ of the national odonatofauna. The share of indigenous species is similar with the 33 species breeding or probably breeding at this site making up $46.5 \%$ of such species recorded so far in Poland. All the species classified as non-indigenous in the quarry are ecologically associated mainly or exclusively with lotic habitats (Bernard et al. 2009), which are not present in the quarry. The results of irregular observations in the "Liban" quarry carried out previously (Miłaczewska 2019) indicate that there may be several other species of odonates that were not recorded in this study. Although these observations provide little evidence of these species breeding there, an irregular, indigenous occurrence seems possible at least in the case of the thermophilic Orthetrum albistylum, O. brunneum and Sympetrum fonscolombii.

Such a large richness of Odonata species in a single limestone quarry, as recorded at the site studied, is exceptional (Rudolph 1976; Koeppel et al. 1995; Kuńka et al. 2008; INULA 2011; Fröhlich et al. 2012; Czerniawska-Kusza and Brożonowicz 2014; Gwardjan et al. 2015). It is also different from that recorded typically at other types of small water habitats. For example, from 327 small anthropogenic water bodies of different kinds (e.g. fishponds, sandpits, clay pits, excavations in peat bogs, drainage ditches) examined by Buczyński (2015) in central-eastern Poland, only a few (fish ponds and excavations in peat bogs) supported similar or slightly higher (up to 38 species) numbers of indigenous species. It is exceptional to record as many as 40 odonate species at a single site (Stark 1977). The high species richness recorded in this study is particularly surprising, since "Liban" limestone quarry is located in the centre of a large city and surrounded by highly urbanized areas. Moreover, it was revealed during a short two-year study.

Central European dragonflies can be categorised by their degree of association with urban environments as: moderately urbanophilous, urbanoneutral, moderately urbanophobic or urbanophobic species (Willigalla and Fartmann 2010). The species recorded in the "Liban" quarry categorized in this way is presented in Table 1. Of the 33 indigenous species, 8 are classified as moderately urbanophilous, and 15 as urbanoneutral. Therefore, $70 \%$ of all the species of indigenous dragonflies recorded in the quarry are considered to be adapted to urban environments, and for which urbanization is not a significant obstacle to their occurrence. On the other hand, the remaining 10 species (30\%) are moderately urbanophobic (9) and urbanophobic (1) odonates. For such species, the colonization of this city environment is hindered by the high degree of anthropogenic transformation of the area. There are similar quantitative relations in terms of the degree of habitat specialization. The majority of the species (20), are generalists and the remaining 13 are habitat specialists (Willigalla and Fartmann 2012). Among the latter, is a species of conservation concern, Leucorrhinia pectoralis, which is legally protected in Poland and also listed in Annexes II and IV of the EU Habitats Directive, for which Natura 2000 sites are being established. This species has already been recorded in Kraków in a small pond located in the southern part of the city (Piksa et al. 2006), so it is possible that "Liban" quarry is a part of a wider (meta)population. L. pectoralis and L. rubicunda are the only species in the quarry, the populations of which are declining in Europe (Kalkman et al. 2010). In addition, the number of sites with L. rubicunda in southern Poland is currently decreasing (Bernard et al. 2009). It is worth noting that these species of dragonflies in the quarry studied were categorized as numerous or fairly numerous. The occurrence of species of dragonflies that are habitat specialists or urbanophobic indicates that they are able to colonize areas even in highly urbanized centres of large cities. This also indicates that the local habitat conditions are suitable for many species of Odonata, which usually do not breed in transformed environments in central European cities (Willigalla and Fartmann 2010). On the other hand, the predominance of eurybionts in this quarry is typical of dragonfly assemblages in small water bodies (Steytler and Samways 1995). Their presence indicates an instability in environmental conditions (Buczyński 1999), which could be the marked inter- and intra-annual fluctuations in the water level, a common feature of the area studied. This result is in accord with the opinion that in cities, due to, among other things, the pollution and eutrophication of habitats, the proportion of resistant eurybiontic species is larger than in less urbanized environments (Buczyński and Lewandowski 2011; Villalobos-Jiménez et al. 2016).

\section{Causes of the local species richness}

Recording in an area of only 10 ha as much as $50 \%$ of the odonate species occurring in the country, including numerous habitat-specialists and species that are declining in the region and throughout the continent, and a high proportion of urbanophobic species indicates 
this area is a centre of biodiversity at the scale of a city or a "secondary biodiversity hotspot" (Harabiš and Dolny 2012). It is worth noting that the importance of the quarry is not only based on the number of species recorded there, but also that almost all of them breed and probably complete their life cycle in this quarry. The results for the "Liban" limestone quarry indicate that not only woodlands (Croci et al. 2008) and ponds (Gledhill et al. 2008), but also even small limestone quarries can play an important role in increasing biodiversity in cities. Thus, in cooperation with naturalists, urban planners and city managers, they should be identified, evaluated and conserved.

High biodiversity of plants and invertebrates in quarries is favoured by the geomorphological heterogeneity and structural diversity of such places. This provides many microhabitats (bare rocks, grassland, wetlands, water bodies, etc.), which can be colonized by various groups of organisms. Also the dynamic nature of these habitats that are mainly in early successional stages is not without significance (Tropek et al. 2010; Bétard 2013). The above factors may also positively contribute to the species richness of Odonata, e.g. the presence of numerous hollows in impermeable ground enable water to accumulate and form small reservoirs, which are valuable breeding habitats for numerous species of dragonflies. In cities, the key factors determining the high diversity of aquatic macroinvertebrates (including dragonflies) include the presence of reservoirs with low nutrient levels, clear water and a rich and diverse immersed and floating vegetation at an intermediate stage of succession (Gledhill et al. 2008; Vermonden et al. 2009; Buczyński and Lewandowski 2011; Goertzen and Suhling 2013; Villalobos-Jiménez et al. 2016). All these features are present in the limestone quarry studied. In addition, the astatic nature of the reservoirs and the high variability in the water level and the area flooded also play an important role. As this quarry has a rocky substrate, this hinders succession and stabilizes the favourable mosaic pattern of biotopes, which undoubtedly promotes the high diversity of dragonflies (Goertzen and Suhling 2013). A key factor in maintaining the alpha diversity of dragonflies is the structure of the vegetation (Steytler and Samways 1995; Goertzen and Suhling 2013; Buczyński 2015), which in the quarry is very strongly differentiated. This is the case for both aquatic, rush, riparian and terrestrial vegetation (meadows and grasslands, shrubby thickets, small stands of trees). These provide the dragonflies, as amphibiotic organisms, with access to suitable habitats at all stages of their life cycle (Willigalla and Fartmann 2012; Kietzka et al. 2018) and enables many species to survive and complete their development within a small area. In spite of this quarry's downtown location and isolation, its proximity to the most important ecological corridor in the city, a large river, has advantages. This corridor provides connectivity and potential population exchange with areas located outside the city, which is of great importance for biodiversity in such urban "green islands" (Snep et al. 2006; Bräuniger et al. 2010).

\section{Conservation of secondary habitats in cities}

The basic threat to the richness of fauna and flora at post-mining sites is their planned transformation or restoration (technical reclamation), which is often synonymous with afforestation or transformation into a recreational area (Tropek and Konvicka 2008; Harabiš and Dolny 2012). This occurs despite the fact that leaving the area to natural, spontaneous succession is a less costly and more environmentally friendly (Beneš et al. 2003; Prach and Hobbs 2008; other references in: Tropek and Konvicka 2008). Reclamation was not necessary in the case of "Liban" quarry, because, as revealed, it is already a very suitable area for odonates. This supports the opinion that such anthropogenic habitats are suitable habitats for a wide range of dragonflies associated with natural water bodies (Buczyński 2015). Despite the fact that odonate communities in the centres of cities are generally poorer than those at the peripheries (Willigalla and Fartmann 2010, 2012; Buczyński and Lewandowski 2011; Villalobos-Jiménez et al. 2016) the quarry studied indicates that even highly modified environments may deserve the attention of conservationists. It is widely recognized that there should be areas with high levels of naturalness in cities, due to their role in increasing biodiversity and the functioning of urban ecosystems (Beninde et al. 2015; Aronson et al. 2017). Also, their psychological, recreational and educational significance for the urban community is very important (Fuller et al. 2007; Lemelin 2007) and the ecosystem services provided by such areas is extremely valuable (Bolund and Hunhammar 1999). Undoubtedly, the place studied is of key importance in determining the biodiversity of the entire city. This information should be used to set priorities for nature conservation in the city. Urban planners should use data on local biodiversity to improve the capacity of the city to host a variety of species. They should recognize that this is vital for both the conservation of natural resources and the needs of society.

One of the main threats to odonate biodiversity in cities is habitat fragmentation, barriers to dispersal and reduction in landscape connectivity (Sato et al. 2008), which may lead to the extinction of local populations (Harabiš and Dolný 2012). In order to maintain a high level of biodiversity (including endangered and urbanophobic species) a threshold value of at least 50 ha of a local habitat patch should left for conservation in cities (Beninde et al. 2015). In the case of "Liban" quarry and its surroundings, the "green" habitat with diversified, semi-natural vegetation covers over 120 ha. Therefore, it should be treated as an important local centre of urban biodiversity, ensuring the existence of a high-quality habitat for water and terrestrial organisms (besides odonates, also plants, amphibians, reptiles, orthopterans etc.). The main conservation measures for the site can be 
summarized as follows. The most important is to leave the area as it is and protect it against major changes in use, especially urbanization. Any development for tourism or recreation purposes (conversion into a city park with standard infrastructure and "arranged" greenery) poses a serious threat, as such a transformation would inevitably involve modification of the hydrological regime, drainage of flooded areas and changes in the structure of water and riparian vegetation, which would make the area less suitable for dragonflies (Goertzen and Suhling 2013). The local odonate assemblage would certainly benefit from the removal of artificially introduced, ornamental fish, as it is documented that their predation may negatively affect the diversity of dragonflies, including sites located in cities (Wittwer et al. 2010; Goertzen and Suhling 2013). It is also important to control the growth of riparian bushes and trees in order to avoid excessive shading of ponds, which is generally disadvantageous for dragonflies (Remsburg et al. 2008). Keeping this quarry free from urban infrastructure is an indispensable prerequisite for maintaining the species richness of the local odonatofauna. It is also a simple and almost costless way to protect anthropogenic habitats that are favourable breeding sites for dragonflies (Buczyński 2015), which decision makers are currently extremely resistant to do. The protection of this and similar patches of wetland would certainly benefit not only dragonflies, but also many organisms associated with water, as odonates are a good umbrella group (Bernard et al. 2002; Oertli 2008). Moreover, due to their attractiveness (Lemelin 2007), dragonflies can attract visitors to such urban oases of biodiversity, thus fulfilling the role of flagship species for wetlands located in cities (Goertzen and Suhling 2013; Villalobos-Jiménez et. al. 2016). The assignment of this area for conserving biodiversity seems to be the best, the simplest and certainly the cheapest way to manage this type of post-exploitation site in cities. This will benefit not only nature, but also society, by providing citizens with easy access to biodiverse sites that are rich in plants and animals, which is becoming increasingly important in the modern world.

\section{Acknowledgements}

I would like to thank Maciej Bonk for his helpful comments on an early version of this manuscript.

\section{REFERENCES}

Aronson MFJ, Lepczyk CA, Evans KL, Goddard MA, Lerman SB, MacIvor JS, Nilon CH, Vargo T (2017) Biodiversity in the city: key challenges for urban green space management. Front Ecol Environ 15: 189-196.

Beneš J, Kepka P, Konvička M (2003) Limestone quarries as refuges for European xerophilous butterflies. Conserv Biol 17: $1058-1069$
Beninde J, Veith M, Hochkirch A (2015) Biodiversity in cities needs space: a meta-analysis of factors determining intra-urban biodiversity variation. Ecol Lett 18: 581-592.

Bernard R, Buczyński P, Tończyk G (2002) Present state, threats and conservation of dragonflies (Odonata) in Poland. Nature Conserv 59: 53-71.

Bernard R, Buczyński P, Tończyk G, Wendzonka J (2009) A distribution atlas of dragonflies (Odonata) in Poland. Bogucki Wydawnictwo Naukowe, Poznań.

Bétard F (2013) Patch-scale relationships between geodiversity and biodiversity in hard rock quarries: case study from a disused quartzite quarry in NW France. Geoheritage 5: 59-71.

Bolund P, Hunhammar S (1999) Ecosystem services in urban areas. Ecol Econ 29: 293-301.

Bräuniger C, Knapp S, Kühn I, Klotz S (2010) Testing taxonomic and landscape surrogates for biodiversity in an urban setting. Landscape Urban Plan 97: 283-295.

Buczyński P (1999) Dragonflies (Odonata) of sandpits in south-eastern Poland. Acta Hydrobiol 41: 219-230.

Buczyński P (2015) Dragonflies (Odonata) of anthropogenic waters in middle-eastern Poland. Wydawnictwo Mantis, Olsztyn.

Buczyński P, Buczyńska E, Michalczuk W (2019) From Southern Balkans to Western Russia: Do First Polish Records of Pantala flavescens (Fabricius, 1798) (Odonata: Libellulidae) Indicate a Migration Route? J Entomol Res Soc 21: 11-16.

Buczyński P, Lewandowski K (2011) Dragonfly (Odonata) fauna of Olsztyn (Poland). In: Indykiewicz P, Jerzak L, Böhner J, Kavanagh B (eds) Urban fauna. Studies of animal biology, ecology and conservation in European cities. UTP Bydgoszcz, pp 109-119.

Bulánková E (1997) Dragonflies (Odonata) as bioindicators. Biologia, Bratislava 52: 177-180.

Chester ET, Robson BJ (2013) Anthropogenic refuges for freshwater biodiversity: their ecological characteristics and management. Biol Conserv 166: 64-75.

Conrad KF, Willson KH, Harvey IF, Thomas CJ, Sherratt TN (1999) Dispersal characteristics of seven odonate species in an agricultural landscape. Ecography 22: 524-531.

Croci S, Butet A, Georges A, Aguejdad R, Clergeau P (2008) Small urban woodlands as biodiversity conservation hot-spot: a multi-taxon approach. Landsc Ecol 23: 1171-1186.

Czerniawska-Kusza I, Brożonowicz A (2014) Zoobenthos in post-exploitation reservoirs of marls and limestone in Opole Silesia. Pol J Natur Sc 29: 307-318.

Fröhlich A, Hauswirth L, Joest R (2012) Natur aus zweiter Hand - Steinbruch Lohner Klei. Erfassung der Flora, Libellen, Heuschrecken und Tagfalter im Naturschutzgebiet "Steinbruch Lohner Klei” 2009-2011. ABU info 33-35: 21-25.

Fuller RA, Irvine KN, Devine-Wright P, Warren PH, Gaston KJ (2007) Psychological benefits of greenspace increase with biodiversity. Biol Lett 3: 390-394.

Gledhill DG, James P, Davies DH (2008) Pond density as a determinant of aquatic species richness in an urban landscape. Landsc Ecol 23: 1219-1230.

Goertzen D, Suhling F (2013) Promoting dragonfly diversity in cities: major determinants and implications for urban pond design. J Insect Conserv 17: 399-409.

Górecki J, Seremet E (2010) Kamieniołomy Krakowa - dziedzictwo niedocenione. In: Zagożdżon P, Madziarz M (eds) Dzieje górnictwa - element europejskiego dziedzictwa kultury. Wrocław University of Technology, Wrocław, pp 123-138.

Grimm NB, Faeth SH, Golubiewski NE, Redman CL, Wu J, Bai X, Briggs JM (2008) Global change and the ecology of cities. Science 319: 756-760. 
Gwardjan M, Przybylska J, Maniarski R (2015) Ważki (Odonata) Kielc. Naturalia 4: 90-107.

Harabiš F, Dolny A (2012) Human altered ecosystems: suitable habitats as well as ecological traps for dragonflies (Odonata): the matter of scale. J Insect Conserv 16: 121-130.

INULA (2011) Dragonflies in quarries and gravel pits. In: Rademacher M (ed) Biodiversity in mineral extraction sites, volume 1. Global Management Biodiversity and Natural Resources, Heidelberg Cement, pp 1-98.

Jefferson RG (1984) Quarries and wildlife conservation in the Yorkshire Wolds, England. Biol Conserv 29: 363-380.

Kalkman VJ, Boudot J-P, Bernard R, Conze K-J, De Knijf G, Dyatlova E, Ferreira S, Jović M, Ott J, Riservato E, Sahlén G (2010) European Red List of Dragonflies. Publications Office of the European Union, Luxembourg.

Kietzka GJ, Pryke JS, Samways MJ (2018) Comparative effects of urban and agricultural land transformation on Odonata assemblages in a biodiversity hotspot. Basic App Ecol 33: 89-98.

Koeppel H-D, Meier C, Warner J (1995) Alter Steinbruch - neue Perspektiven. Die Rekultivierung des Steinbruchs Schümel in Holderbank und seine Zukunft. HCB Zementproduktion, Siggenthal.

Krauss J, Alfert T, Steffan-Dewenter I (2009) Habitat area but not habitat age determines wild bee richness in limestone quarries. J App Ecol 46: 194-202.

Kuńka A, Hebda G, Łęgowski D, Świerad R (2008) Faunistical data on selected species of dragonflies (Insecta: Odonata) of the Opole Province (Southwest Poland). Opole Scientific Soc Nature J 41: 101-105.

Kutcher TE, Bried JT (2014) Adult Odonata conservatism as an indicator of freshwater wetland condition. Ecol Indic 38: 31-39.

Lemelin RH (2007) Finding beauty in the dragon: The role of dragonflies in recreation and tourism. J Ecotourism 6: 139-145.

Miłaczewska E (2019) Kamieniołom Liban. http://www.wazki.pl /krakow_liban.html. Accessed 5 January 2019.

Oertli B (2008) The use of dragonflies in the assessment and monitoring of aquatic habitats. In: Córdoba-Aguilar A (ed) Dragonflies and damselflies: Model organisms for ecological and evolutionary research. Oxford University Press, Oxford, pp 79-95.

Osborn R (2005) Odonata as indicators of habitat quality at lakes in Louisiana, United States. Odonatologica 34: 259-270.

Piksa K, Wachowicz B, Kwarcińska M (2006) Dragonflies (Odonata) of some small anthropogenic water bodies in Cracow City. Fragm Faun 49: 81-89.
Prach K, Hobbs RJ (2008) Spontaneous succession versus technical reclamation in the restoration of disturbed sites. Restor Ecol 16: 363-366.

Remsburg AJ, Olson AC, Samways MJ (2008) Shade Alone Reduces Adult Dragonfly (Odonata: Libellulidae) Abundance. J Insect Behav 21: 460-468.

Rudolph R (1976) Die Libellenfauna des NSG Steinbruch Vellern. Natur und Heimat 36: 25-29.

Sato M, Kohmatsu Y, Yuma M, Tsubaki Y (2008) Population genetic differentiation in three sympatric damselfly species in a highly fragmented urban landscape (Zygoptera: Coenagrionidae). Odonatologica 37: 131-144.

Snep RPH, Opdam PFM, Baveco JM, WallisDeVries MF, Timmermans W, Kwak RGM, Kuypers V (2006) How peri-urban areas can strengthen animal populations within cities: A modeling approach. Biol Conserv 127: 345-355.

Stark W (1977) Ein Teich in der Steiermark (Österreich) als Lebensraum für 40 mitteleuropäischen Libellenarten. Entomol Z 87: 249-263.

Steytler NS, Samways MJ (1995) Biotope selection by adult male dragonflies (Odonata) at an artificial lake created for insect conservation in South Africa. Biol Conserv 72: 381-386.

Tropek R, Kadlec T, Karesova P, Spitzer L, Kocarek P, Malenovsky I, Banar P, Tuf IH, Hejda M, Konvicka M (2010) Spontaneous succession in limestone quarries as an effective restoration tool for endangered arthropods and plants. J App Ecol 47: 139-147.

Tropek R, Konvicka M (2008) Can quarries supplement rare xeric habitats in a piedmont region? Spiders of the Blansky les Mts, Czech Republic. Land Degrad Dev 19: 104-114.

Vermonden K, Leuven RS, van der Velde G, van Katwijk MM, Roelofs JG, Hendriks AJ (2009) Urban drainage systems: An undervalued habitat for aquatic macroinvertebrates. Biol Conserv 142: 1105-1115.

Villalobos-Jiménez G, Dunn AM, Hassall C (2016) Dragonflies and damselflies (Odonata) in urban ecosystems: a review. Eur J Entomol 113: 217-232.

Willigalla C, Fartmann T (2010) Libellen-Diversität und -Zönosen in mitteleuropäischen Städten. Ein Überblick. NuL 42: 341-350.

Willigalla C, Fartmann T (2012) Patterns in the diversity of dragonflies (Odonata) in cities across Central Europe. Eur J Entomol 109: 235-245.

Wittwer T, Sahlén G, Suhling F (2010) Does one community shape the other? Dragonflies and fish in Swedish lakes. Insect Conserv Diver 3: 124-133. 